\title{
PROBLEMS OF THE EFFECTIVE IMPLEMENTATION OF SUBJECTIVE CIVIL LAW IN TIME
}

Guyvan P. D.

\section{INTRODUCTION}

Legal relations create specific social opportunities for legal entities to satisfy their specific needs with their own actions or with the actions of other entities, and represent an ideological public relation provided for by the hypothesis of a legal norm, which is expressed in mutual legal rights and obligations of legal entities. Moreover, the substantive law that mediates these relations must meet the criteria of clarity, expectation, certainty and effectiveness. A change in ideology leads to the need to introduce new ideals and values into the national legal culture that determine the reform of domestic legislation. In these conditions, there is a need to develop modern methodological approaches that would allow us to consider law as one of the most important elements of human life ${ }^{1}$. The issue of the effectiveness of legal requirements is very relevant for Ukraine. The effectiveness of law as a social phenomenon includes the whole range of issues, from legal understanding, law-making, the functions of law, and ending with the actual effect of law and its forecasting.

In the temporal dimension, important factors ensuring the proper effectiveness of a legal norm are its certainty, predictability and timeliness. Indeed, negative social consequences can be caused by the delayed regulation of social relations by laws that have long been taking place, and the premature consolidation of relations in normative regulatory acts that have not yet acquired relevance. It is important that the concept of law is directed by its semantic vectors into the future. For this, it is necessary to limit the reverse effect of legal norms to the maximum extent possible in time, guarantee public awareness of their contents (apply only promulgated acts), and ensure their fair enforcement. The effectiveness of law is the correspondence of the actual results of the implementation of the rule of law in accordance with the declared goal ${ }^{2}$.

The effectiveness of legal regulation is a rather important indicator of a proper and fair legal system. The issue of the effectiveness of legal support of certain social and legal relations was considered in the scientific

\footnotetext{
1 Завальнюк В.В. Антропологічне осягнення правової реальності: юриспруденція на перетині епох : монографія. Одеса : Юрид. л-ра, 2012. С. 4.

2 Рабінович П.М. Ефективність права. Юридична енциклопедія: у 6 т. / за ред. Ю.С. Шемшученка та ін. Київ : Укр. енцикл, 1999. Т. 2. Р. 369.
} 
literature by such scientists as O.S. Ioffe, M.M. Agarkov, V.P. Gribanov, S.M. Bratus, E.O. Michurin, N.I. Kozyubra, V.V. Zavalnyuk, S.A. Zhinkin, L.I. Petrazhitsky, D. Gritsenko, L. Fuller, A.F. Skakun, V.S. Nersesyants, A.I. Khoroshiltsev and others. However, a holistic concept on this issue has not been developed. Basically, these works were limited to an analysis of the quantitative characteristics and scope of powers included in the content of the law, and the results of its implementation in excess of precisely these indicators. Serious scientific studies of the timeliness of the implementation of subjective law in civilian literature have not been conducted; in the temporal aspect, the question of the effectiveness of legislative provisions has not been studied. So, the goal and objectives of the article is to study modern concepts about the effectiveness of law, with emphasis on the enforcement of the Ukrainian system. The concept of the effectiveness of regulatory requirements as a socio-legal regulator of public life is evaluated in the context of their clarity, consistency, accessibility and aspiration for the future, which ensures the stability of legal regulation. For a more thorough knowledge of the subject of study, the legal tools are analyzed, according to which public authorities are limited in their actions to pre-established and announced rules that make it possible to predict with great accuracy the measures that will be applied by representatives of the authorities in a given situation, taking into account which an individual may confidently plan your actions.

In the practice of applying the civil law institution, a number of controversial issues have been identified. First of all, this concerns the problems of their calculation, the legal consequences of the expiration of certain periods, the procedure for applying uncertain terms and the like. To solve them, it is necessary to apply the general conceptual framework developed by the civilist theory, while taking into account the real nature of the actual relationship. This approach will eliminate contradictions and, most importantly, the artificiality of the legal regulation of individual relations that do not correspond to their legal content. A scientific study of the temporal dimensions of the implementation of a legal opportunity inherent in subjective law is the goal of this work.

\section{Temporary parameters for the implementation of civil relations}

Any subjective law is valuable only because it can be used to satisfy the needs of an authorized person, that is, due to the possibility of realizing the law ${ }^{3}$. So, being the subject of a certain substantive law, a person will

3 Грибанов В.П. Пределы осуществления и защиты гражданских прав. Москва : Российское право, 1992. Р. 11. 
certainly receive the corresponding degrees of freedom, within the limits of which, by his behavior, he can turn the possibilities inherent in subjective law into the necessary material result. One of the factors that limits the freedom of an authorized person in the exercise of subjective law may be time. Almost always, subjective law has certain boundaries, not only in content or methods of its implementation, but also limited in time. Civil rights with indefinite content or those that do not imply their physical exercise cannot arise. The same applies to subjective rights, the life of which is zero. So, each substantive law must have a validity period during which it can be realized.

Ensuring the interests and needs of a person is the main purpose of law, measuring its effectiveness. The need for the development of law is realized on the basis of its interaction with accepted spiritual values and ideals in society. And this is possible only if the law corresponds to the socio-psychological and cultural-historical foundations of society ${ }^{4}$. Social life is regulated by issuing legal acts and monitoring their implementation. The fundamental legal principles are implemented, of course, in the law-making system, but their effectiveness is manifested in law enforcement. The principles of law reflect legal ideas. It is through the proper application of legal requirements that these legal ideas gain their realization. Consequently, the concept of the effectiveness of legal norms is associated primarily with the effectiveness of their application. Moreover, the effectiveness is closely related to the criteria and conditions of such enforcement. This happens both in the practical implementation ofregulatory relations, and within the framework of a protectiverelationship. Moreover, the significance of the latter lies in the fact that the protection of the violated subjective substantive law occurs in the framework of new relations that did not exist before the offense. Therefore, here the most important factors are the predictability and predictability of the protective response of a person to violations.

Actually, in the scientific literature the idea was expressed that the legal regulation of existing relations is doomed to acquire signs of effectiveness. Ineffective regulation, in principle, is meaningless: it is necessary to try by all means both at the level of law-making and at the level of legal realization to promote the development of effective, efficient mechanisms of legal influence. Large-scale catastrophic events of the last century proved the reality of the harm done to a person as a result of total control by

4 Гриценко Г.Д. Право как социокультурное явление (философско-антропологическая концепция) : дис. ... докт. филос. наук. Ставрополь, 2003. Р. 48. 
the authorities, the state's attempt to regulate not only social behavior, but also the internal, spiritual life of the individual. The damage caused illustrates that the effectiveness of law can be anti-legal in nature, and even contradict the main goal of the law itself - the implementation of the principles of justice and humanism in public life ${ }^{5}$. At one time, Hegel introduced the definition of "wrong" as a category opposite to law. By this phenomenon, he understood the will of the power subject, aimed at demonstrating arbitrary power, which significantly distances itself from public will and law. Therefore, "wrong" was formulated as the appearance of an entity that defines itself as an independent phenomenon ${ }^{6}$. Consequently, the issue of the effectiveness of law intersects with the problem of the quality of legislation in the context of its focus on ensuring ideas of freedom, humanity and justice, and in the end, achieving the necessary balance between positive and moral law. This shows the quality of law and its close relationship with the effectiveness of regulation of public relations. The effectiveness of the legal impact is determined by the positive consequences for the development of a particular individual and society as a whole. The effectiveness of legal regulation is the practical side of the manifestation of the category "quality of law". The norm of law receives real being in the process of implementation, interaction with specific social relations. Outside practice, the effectiveness of a legal norm is not revealed. So, the effectiveness of law and its real properties can be considered as an external manifestation of the quality of law.

In the literature, a legal term is qualified as an objectively existing relationship between legal phenomena, which is manifested in a certain number of qualitative changes in legal phenomena, expressed in terms of calendar time, emerging in a certain sequence, and changes as a result of the interaction of legal phenomena with each other ${ }^{7}$. In our opinion, such a definition has the disadvantage that it confuses the concepts of the term as a legal category with the consequences that its expiration or occurrence leads to. Civil relations, subjective rights and obligations of their participants are also formed, developed and terminated over time. This time is determined either in the normative order, or by the participants in the relations

\footnotetext{
5 Завальнюк В.В. Ефективність права: антропологічний та євроінтеграційний аспекти. Lex portus. 2017. № 1 (3). P. 40-41.

6 Гегель Г.В.Ф. Основи філософії права, або Природне право і державознавство / пер. 3 нім. Р. Осадчука, М. Кушніра. Київ : Юніверс, 2000. Р. 88-89.

Щербаков О.В. Понятие юридического срока и его процессуальный режим. Проблемь совершенствования законодательства Украины и практики его применения : Краткие тезисы докл. и науч. сообщ. межрегиональной научной конференции молодых учёных и соискателей. Харьков : УЮА, 1991. Р. 25.
} 
themselves. But in any case, the duration of certain phenomena having legal significance reflects the social need for the manifestation of the influence of time on their existence. The effect of civil rights and obligations over time very significantly affects the behavior of participants in relations. By providing temporal certainty to a subjective law or legal obligation, the terms thereby contribute to streamlining the material relationships, responsibility and discipline of their participants. It is such a regulatory influence of time on the activities of individuals and legal entities that ensures its significance and acceptability.

The main criterion for the effectiveness of a legal norm is the effectiveness of its practical implementation by law enforcement authorities; therefore, factors that are in the sphere of legal implementation determine the real effectiveness. This may include the security of certain requirements with material and organizational resources, compliance with the norms of public thought, the clear work of law enforcement agencies, etc. ${ }^{8}$. Actually, the effectiveness of a legal act is determined by its ability to influence social relations in a direction useful to society. In other words, the effectiveness of law is determined by its feasibility, which, in turn, is due to the general knowledge, comprehensibility and consistency of legal norms, their systematic nature (for example, the seamlessness of the relations of substantive and procedural norms), the conformity of the social goals of the norms and legal means of their achievement, security law an effective system of justice and other law enforcement agencies ${ }^{9}$. In the temporal sense, the effectiveness of law is achieved through proper knowledge and knowledge of the legal process that allows you to expect proper enforcement, predict its results, and therefore the future state of the legal system, prevent negative consequences, reduce possible risks.

The content of subjective law is the amount of authorized behavior of an authorized person that he can exercise to exercise his right. In other words, subjective law is a measure of the possible conduct of an authorized person. In civilistic science, it is convincingly proved that possible behavior, which constitutes the content of subjective law, and behavior aimed at the implementation of law, are correlated as an opportunity and reality ${ }^{10}$. Realizing his right, the subject performs real volitional actions, turning this

\footnotetext{
8 Жинкин А.В. Некоторые проблемы видов эффективности норм права. Журнал российского права. 2004. № 2. С. 30-31.

9 Лейст О.Э. Сущность права: Проблемы теории и философии права. Москва: ИКД «Зерцало-М», 2002. 288 c.

10 Иоффе О.С., Грибанов В.П. Пределы осуществления субъективных гражданских прав. Советское государство и право. 1964. № 7. Р. 77.
} 
opportunity into reality. Subjective law may arise as a result of the will of the person. Thus, concluding a lease of property, the tenant creates through his actions the right to use and possess certain property. However, subjective law may arise in addition to the will of the authorized person. For example, such is the right of a citizen to a will, the right to compensation for harm and the like. On the contrary, the realization of subjective law occurs as a result of specific willful actions of a person aimed at transforming the possibilities of behavior inherent in law into reality. In these actions is reflected not only the will of the subject, but also the specific features of a particular case.

As a matter of fact, each subjective right as a measure of possible behavior has corresponding limits. In the literature, there has been and continues to be a discussion about the absence of such boundaries in the exercise of property rights. According to F.K. Savigny and his followers, the right of ownership is by its nature an unlimited right, it provides the subject with the opportunity to receive any benefit from the use of property, regardless of any other circumstances. In this context, civil scientists pointed out the limited ownership of the rules of law, therefore, noted that the owner's power over a thing was carried out only within the limits defined by law, as for time restrictions, then there should not be any ${ }^{11}$. It is hardly possible to support such a thesis. We believe that his supporters confuse the existence of the law itself and its belonging to a specific person. Indeed, subjective law is therefore called subjective because it has its bearer. And the latter cannot exist forever (liquidation of a legal entity, death of an individual). The same applies to the limited existence in time of the object of ownership (destruction, consumption of things, etc.).

Today, civil law is dominated by the position that the property right of a person cannot be used contrary to the law and moral principles of society, to the detriment of the ecological state, rights, freedoms and interests of others. Otherwise, the exercise of the property right should be qualified as an abuse of the right ${ }^{12}$. The corresponding rule was reflected in the Civil Code of Ukraine (see article 319 of the Civil Code). The form of implementation of the principle of justice, good faith and reasonableness is a procedure for the implementation of its requirements in the behavior of subjects of civil turnover, in the relationship between them. In material relations, the implementation of the principle of justice and reasonableness, as a rule,

11 Шершеневич Г.Ф. Учебник русского гражданского права (по изданию 1907 г.). Москва : Фирма «СПАРК», 1995. Р. 232.

12 Общая теория права и государства : учебник / под ред. В.В. Лазарева. Москва : Юристь, 1999. P. 288. 
is associated with the establishment of the boundaries of the subjective material rights of counterparties. Consequently, the position expressed in science regarding the limitations of any subjective law looks quite certain. But this only applies to the existence of the boundaries of the behavior of the authorized entity regarding the content of the law (for example, they can be determined by law or an agreement) or the method and nature of its implementation (in this regard, the limits of law should take into account the provisions of the law, the moral foundations of society, the rights and interests of others). As for the terms of existence of subjective law as one of the factors affecting the face of a person's behavior, the provision on limiting the right to certain periods is not generally accepted. We consider this a significant doctrinal flaw.

The scientific literature has repeatedly noted that subjective substantive rights cannot be unlimited. Civil law does not boil down solely to the possibility of exercising the rights of an authorized person and their protection. It is also interested in ensuring stability and certainty of legal relations, in protecting the rights and interests of others, the basic principles of society, and the like. It is with the aim of ensuring these interests that the legislation establishes a certain framework for the implementation of subjective civil rights, including temporary ones ${ }^{13}$. Indeed, the absence of a deadline established at the regulatory level for the lender of the testator to apply to the heirs would lead to a long uncertainty regarding the burden of the hereditary mass and would often lead to the impossibility of regulating hereditary relations. The same consequences would entail, for example, the failure to establish the terms of work or the time of acceptance in the contract. Thus, we can agree that the establishment of the boundaries for the exercise of civil rights is not a restriction of these rights, but rather the streamlining of existing material relations ${ }^{14}$.

\section{Correlation of the concepts of "untimely exercise of law" and "abuse of law"}

An important feature of subjective substantive law is the provision of a real possibility of its implementation by the creditor. We repeat, each substantive law must have a validity period during which it can be realized. Therefore, the period of existence of subjective law cannot be "immediate".

13 Гуйван П.Д. Правовая природа гражданско-правовых сроков. Legea si viata. 2015. № 6/2 (282). P. 26-28.

14 Гуйван П.Д. Теоретичні питання строків у приватному праві : монографія. Харків : Право, 2014. Р. 257-268. 
In our opinion, a regulatory clarification of the content of such a period should be made. Firstly, although the law uses the indicated term to describe the time during which the debtor is obliged to fulfill the obligation, it nevertheless fully applies to the existence of the creditor's subjective right. Indeed, the action in time of a subjective legal obligation corresponds to the same subjective civil law in terms of duration. And, as mentioned above, civil law cannot exist only a moment, since the initial and final dates coincide. Therefore, secondly, it is necessary to agree with the opinion expressed in the scientific literature that, when the legislator considers it necessary to instantly (immediately) fulfill an obligation, then this term should be understood as the minimum reasonable period necessary to perform a specific action, as a result of which the implementation of subjective law ${ }^{15}$.

In civil law, the point of view is generally accepted, according to which the implementation of subjective law is the performance by the creditor of certain actions within the framework of the powers that exist as a subject of the law ${ }^{16}$. If the ways of exercising the right go beyond the established limits of its exercise, this is qualified as an abuse of law. The foregoing is largely true in the exercise of the right contrary to its purpose or to the detriment of the interests of others. In particular, the legislation of many countries expressly prohibits the so-called chicane: the use of law solely for the purpose of harming another person. However, not all researchers support the point of view about the possibility of abuse of subjective law, as well as about exceeding the limits of its implementation. From this point of view, it is believed that the introduction of individual freedom into the framework of material obligation is already a limitation. These boundaries oppress, reduce individual freedom, therefore, noted F.K. Savigny, deserve legal protection only as much as it is positively required by the need for civil turnover ${ }^{17}$. It is precisely this reason for limiting contractual liability in certain Ukrainian laws that E.O. Michurin $\operatorname{sees}^{18}$. At the same time, supporters of this theory indicate that the abuse of the right is in fact a violation of specific legal requirements, since the person acts contrary

\footnotetext{
15 Боднар Т.В. Строк (термін) виконання договірного зобов'язання в цивільному праві України. Вісник господарського судочинства. 2004. № 2. С. 210.

16 Луць В.В. Строки і терміни у цивільному праві : монографія. Київ : Юрінком Інтер, 2013. C. 12.

17 Нолькен А. Договоры в пользу третьих лиц. Санкт-Петербург : Типография императорской академии наук, 1885. С. 68.

18 Мічурін Є.О. До прроди обмежень майнових прав фізичних осіб. Форум права. 2006. № 3. C. 84 .
} 
to the established rule, and this action is fully covered by dispositions of specific prohibiting norms of civil law. Therefore, there is no place left for the design of abuse of the right: actions that seem to be abuse of the right are actually committed outside the law when a person crosses the boundaries of what is permitted and contrary to the law ${ }^{19}$.

We cannot support such a scientific approach. Let's take a closer look at the discussion in the context of studying the commented link. Indeed, a person can, within the limits of the existence of his subjective right (including during the term of validity), independently choose the methods and direction of its implementation. Among the latter there may be those that, for example, harm other copyright holders. Say the car owner parks it in such a way that it prevents other people from driving into their home or garage. Here, the owner acts in his own right, but its implementation harms the surrounding entities. Such misuse of the right should be qualified as abuse. At the same time, it should be recognized that the abuse of law is not related to the content of the law itself, but to its implementation, therefore, the performance of certain actions, both legitimate and illegal, outside the scope of the content of the law should be qualified as those that are not based on subjective law.

There is another point of view: the exercise of subjective law outside its limits or content ${ }^{20}$ is also an abuse of law. However, the fallacy of such a position is highlighted in the analysis of the possibilities of realizing substantive law outside the hourly boundaries of its existence. Regarding the exercise by the creditor of the powers constituting the content of subjective law, before the beginning of the existence or after the end of the law, M.M. Agarkov's statement will be fair that such actions occurred outside the law and therefore cannot be considered an abuse of law ${ }^{21}$. It is clear that the presentation by the authorized person of claims outside the limits of the flow of the exercise of the right will make it impossible to exercise it. A person has committed a legally significant act outside the terms of existence of a certain subjective law, therefore it will be erroneous to consider him a subject that exercises (applies) his right. Such actions should not be regarded as an abuse of law, but as unlawful. It should be noted that the commission of certain actions that do not follow from a person's

\footnotetext{
19 Агарков М.М. Проблема злоупотребления правом в советском гражданском праве. Москва : АН СССР, 1946. № 6. С. 426.

20 Флейшиц Е.А. Обязательства из причинения вреда и из неосновательного обогащения. Москва : Госюриздат, 1951. С. 50.

21 Агарков М.М. Проблема злоупотребления правом в советском гражданском праве. Москва : АН СССР, 1946. № 6. С. 427.
} 
subjective civil law is not identical with the wrongfulness of an act. Actions may be recognized as unlawful if they contradict the legislative requirements. In the case when the actions, although not based on the subjective right of the person, do not conflict with the requirements of the law and meet the criteria of interest of the person, they must be recognized as legitimate (part 2 of article 15 of the Civil Code of Ukraine), but not entailing desired effects.

Limitations in the law of obligations were identified by some scientists with socially significant goals at the general scientific level. The exercise of subjective law outside of its existence cannot be qualified as an abuse of the law, since the law is actually still or is not there. As M. Planiol aptly said, law either ceases or abuse begins (Le droit cesse ou l'abus commence) ${ }^{22}$. Therefore, actions that correspond to the volume of the subjective powers of a person, but are carried out outside the period of their existence, should be considered only as the implementation of actions that do not constitute the full content of the law, that is, as committing them without proper justification. As a result, there may be a refusal to protect the right in connection with the non-ownership of this person. In this context, one cannot agree with the assertion that the use of law outside its scope is an abuse of law ${ }^{23}$, since no right already exists. To abuse the right, it is necessary, at a minimum, to own it, since this manifestation, in the absence of a right, is a behavior contrary to the law and, therefore, falls within the definition of a common offense ${ }^{24}[18$, p. 63]. According to the current Ukrainian civil law, only acts to exercise his right to the detriment of other persons, cultural heritage, contrary to the law or moral principles of society (Article 13 of the Civil Code of Ukraine) are considered unlawful and punishable. Thus, the concept of abuse of law does not cover cases of its implementation outside (including temporary) of its existence.

So, the abuse of the right is possible only during the period of its existence by performing certain actions in its own right, but these actions should be directed against the interests of other persons protected by law. Elements of abuse may be non-compliance with the content of subjective law in terms of the scope or purpose of its implementation. But, as we see, substantive law can be exercised by the bearer at any moment of its

\footnotetext{
22 Planiol M., Ripert G. Traite elementaire de driot civile. Paris, 1946. P. 157.

23 Поротикова О.А. Проблема злоупотребления субъективным гражданским правом. Москва : Волтерс Клувер, 2008. С. 154.

24 Малеин Н.С. Гражданский закон и права личности в СССР. Москва : Юридическая литература, 1981. С. 63.
} 
operation, "untimely" exercise of the law during its lifetime cannot be qualified as abuse. Nevertheless, one hears a statement like the fact that subjective law, being realized "at the wrong time" during its operation, can also violate the interests of others, therefore it can be qualified as abuse. This position deserves a critical assessment.

A literal interpretation of the provisions of Ukrainian legislation allows us to conclude that the legal nature of regulatory and protective obligation relations is identical, in particular with regard to the temporal boundaries of their implementation. If we extrapolate the above provisions on the belonging of the exercise of the law to certain periods of its existence in a protective legal relationship (for example, those that are manifested in the exercise of a person's material right to claim), we can conclude that recourse to judicial protection in certain periods of limitation should be qualified as the exercise of a right against its purpose. For example, when the defendant is ill and the like. Let us categorically disagree with this thesis. The time for exercising the right within the period of its existence cannot affect the choice of the method of its implementation (for example, in the example we have given now, the respondent's illness is taken into account by other legal mechanisms, for example, procedural). Choosing the period and method of exercising his authority within the scope and duration of the law, the person makes its implementation. By exercising the law inappropriately, it thereby replaces the permitted forms of behavior with the illegal ones. But the time period established for the implementation of subjective law determines the boundaries of the possible behavior of the copyright holder in the understanding of the presence or absence of a subjective right at a given moment. After the termination or before the beginning of the validity of the right, abuse cannot be due to the fact that the person involved does not have the right, the manifestation of which he commits. Therefore, any cases of the realization of the right "not at that moment" during its operation are not included in the concept of abuse.

\section{Temporal certainty of enforcement: European experience}

Based on the distinction between the areas of lawmaking and law enforcement, there is a permissive assessment of the effectiveness of the adoption and implementation of a legal act. Each legal requirement is only an opportunity that must be realized to one degree or another. Consequently, efficiency is not a feature of legal regulation, but an objective opportunity, which, in order to turn it into reality, requires compliance with a number of rules. In the process of lawmaking, we can only talk about 
predicted, potential effectiveness. When implementing the relevant norm, its real effectiveness is manifested. It can be higher than predicted (in this case, the effect produced by the norm is influenced by circumstances whose action the legislator did not take into account or underestimated). However, in practice, more often than not, the effectiveness of a legal norm is lower than that which the legal creator sought ${ }^{25}$. In practical terms, the principle of the effectiveness of law has been widely embodied in the practice of the European Court of Human Rights. The principle of the effectiveness of law upheld by the ECHR is that the parties to the case have the right to submit comments that they consider important. This right can be considered effective only if the comments were "heard", that is, they were accordingly examined by the court. So the "court" must conduct due consideration of the submitted documents and evidence, as well as the arguments provided by the parties (case "Kraska v. Switzerland") ${ }^{26}$. Consequently, the issue of implementing the principle of fair trial is sufficient complex and debatable, while it should clearly distinguish between the justice of the trial and the correctness or falsity of the judgment ${ }^{27}$.

Violation of these requirements of a fair process as a result leads to the adoption of an illegal decision. Thus, the ECHR decision in the Bendersky v. Ukraine case found a violation of Article $6 \S 1$ of the Convention for the Protection of Rights and Fundamental Freedoms of 1950 due to the fact that the domestic courts did not examine the applicant's references to the testimony of the doctor who observed him after the operation on the bladder, although the latter were important for the proper resolution of the case on the applicant's claim to the private hospital for termination of the contract for the provision of medical care and compensation for harm caused as a result of the operation carried out by the defendant. As the Court points out, such a violation consists in the fact that a certain argument by the plaintiff was, if not decisive, at least very important for the settlement of the dispute and thus required a special and clear response from the courts. In the absence of any reaction to such an argument, the Court considers that the Ukrainian judicial authorities did not provide the applicant with the right to a fair trial within the meaning of Article $6 \S 1$ of the Convention, therefore,

25 Шаргородский М.Д. Наказание, его цели и эффективность. Ленинград : Издательство Ленинградского университета, 1973. С. 58.

26 Decision of the ECHR of April 19, 1993 in the case of Kraska v. Switzerland, № 13942/88, URL: http://echr.ketse.com/doc/13942.88-en-19930419. § 30.

27 Трегубов Е.Л. Право на справедливий суд в практиці європейського суду з прав людини. Форум права. 2010. № 1. С. 360. 
there was a violation of this provision ${ }^{28}$. Consequently, the court's refusal to take into account the factual circumstances of the case, which were significant in the resolution of the dispute, may lead to a violation of Article 6 para. 1. Unfortunately, Ukrainian courts quite often neglect the abovementioned fundamental principles. Let’s say in case № 553/1254/16-c, the courts, both local and appeal and cassation, did not take into account the testimonies of numerous witnesses to the fact that the violation of the Rules for the use of electric energy by the plaintiff (unauthorized connection to the network) lasted one hour. At the same time, the courts without any evidence recognized the truth of the allegations of PJSC Poltavaoblenergo that unauthorized open connection lasted 339 days $^{29}$. It is a pity that the latest decision in this case was recently taken by the newly created Supreme Court. As you can see, this body is also characterized by ignoring the European principles of certainty and effectiveness of law.

In the area of temporal regulation of fair trial, the effectiveness of a legal norm is associated with a reasonable length of court proceedings and the execution of final court verdicts. Demanding the observance of the principle of reasonable deadlines for the process, the Convention for the Protection of Human Rights and Fundamental Freedoms is interpreted by the European Court as an instrument that emphasizes that justice is not sent with a delay that could compromise its effectiveness and credibility ${ }^{30}$. Moreover, this principle covers not only the tools for the implementation of timely justice, but also is used to regulate the relevant actions of the participants in the process. For example, the decision of the ECHR in the case of "Ponomarev v. Ukraine" states that the parties should take measures at reasonable intervals to find out about the state of the court proceedings known to them. If the defendant is duly notified by the court of the time and place of the settlement of the dispute with his participation, it is considered that he exercised his right to participate directly in the hearing. And he had enough time to present evidence and justify his objection and refutation of the claim $^{31}$.

It should be noted that the Ukrainian law enforcement system in this regard is quite confident in perceiving individual European principles. In particular, the issue is now resolved, which until recently was very

28 Decision of the ECHR of November 15, 2007 in the case of Bendersky v. Ukraine, stated. № 22750/02, URL: http://zakon3.rada.gov.ua/laws/show/974_313. § 46, 47.

29 Справа № 553/1254/16-ц. Архів Ленінського районного суду м. Полтава за 2016 рік.

30 Decision of the ECtHR of February 20, 1991 in the case of Vernillo v. France, № 11889/85. URL: http://echr.ketse.com/doc/11889.85-en-19910220/. §38.

31 Decision of the ECHR of April 3, 2008 in the case of Ponomarev v. Ukraine, № 3236/03. URL: http://zakon5.rada.gov.ua/laws/show/974_434. § 41. 
relevant in terms of appealing to the court for the prosecutor. Previously it was believed that the statute of limitations for a statement of claim by a prosecutor should be calculated from the moment when he personally learned about the violation of the right of the person for whose protection he goes to court. Now the approach has changed, and the general procedural requirements are recognized as binding on all participants in the process, therefore, the provisions of the law on the beginning of the term for applying to the court apply to the appeals of the prosecutor to the court to protect the interests of the person. By adopting ruling № 6-178tss15, the Supreme Court of Ukraine applied articles 256, 261 of the Civil Code of Ukraine to article 161 of the Law of Ukraine "On the Prosecutor's Office" and came to the conclusion that the prosecutor participating in the case bears obligations and enjoys the rights of the party, except the law to conclude a settlement agreement. Therefore, the provisions of the law on the beginning of the limitation period apply to the prosecutor's appeal to the court with a statement on the protection of state interests. Making a decision in the case, the court of the previous instance did not take into account the provisions of the law and came to the erroneous conclusion about the beginning of the limitation period from the day the prosecutor discovered violations of land legislation during the prosecutor's inspection ${ }^{32}$.

But the Ukrainian justice can not cope with the preparation of the case for consideration, the process and the implementation of final decisions within a reasonable time. Courts must prepare civil cases for trial and consider them within the time limits set for this. The Supreme Court of Ukraine drew the attention of judges to the need to increase personal responsibility for the timely and quality consideration of court cases, bearing in mind that a full, comprehensive and objective review of cases in compliance with the deadlines established by law is their responsibility ${ }^{33}$. In cases where the statutory deadline for the consideration of the case is calculated from the day the application is received, the preparation of the case must be completed so that it is considered within that time in compliance with the rules on the timing of the subpoena, unless otherwise follows the law. Unfortunately, de facto today, almost all court cases are considered with a significant excess of the deadlines established for this, sometimes for years, and most of these delays are unjustified.

32 Постанова Верховного Суду України від 01 липня 2015 р. у справі № 6-178цс15. URL: http://www.reyestr.court.gov.ua/Review/46301621.

33 Постанова Пленуму Верховного Суду України «Про строки розгляду судами України кримінальних і цивільних справ» від 01 квітня 1994 р. № 3. URL: http://zakon3.rada.gov.ua/ laws/show/v0003700-94. §1. 
It should be noted that the ECHR has consistently indicated not the impossibility of applying unannounced legal acts. Their similar use will be ineffective, because the principle of expectation and predictability is violated, which will make it impossible for a person to predict his behavior. In this case, the moral obligations of the legislator regarding the promulgation of their acts should be taken into account. This is indicated in his work "The Morality of Law" by Lon Fuller. "For example, a custom can determine what type of promulgation of laws is expected, while leaving it unclear what consequences will be deviation from the accepted method of publication. Providing an official form to the requirements of publicity has undoubted advantages over efforts not directed in a certain direction, even if they are applied reasonably and in good faith. The formalized standard of promulgation not only tells the legislator where to publish laws; he also tells the person (or lawyer who represents his interests) where to go in order to find out about the content of the law. It can be assumed that the fundamental requirements that condemn laws with retroactive effect can very easily acquire the official form of a simple rule, according to which no such law will be adopted or enforced. However, such a rule would do a disservice to the cause of law. It is interesting that one of the supposedly obvious requirements of the rule of law: the norm adopted today should regulate what will happen tomorrow, and not what happened yesterday, turns into one of the most difficult problems of all the internal morality of law"34.

Indeed, it is easy to see the seriousness of the problem of the effectiveness of the implementation of the rule of law when applying the law "retroactively". The ECHR points out that the retrospectiveness of civil law is not strictly prohibited by the provisions of the Convention. However, when the question is about an effective remedy, that remedy must exist with a sufficient degree of certainty. Bearing this in mind, the Court considers that the application of time-reversed civil procedure legislation would violate the principle of legal certainty and is incompatible with the provisions of the law if it deprives a person of access to legal remedies that must be effective in accordance with the provisions of Article $35 \S 1$ of the Convention ${ }^{35}$. A similar approach is applied when, when the adoption of the relevant act during a specific process, deprives the production of legal force. Laws must be issued at the beginning of proceedings or after their completion. In any case, the normative act must have a transitional adaptation period.

\footnotetext{
34 Fuller L. The Morality of Law. Yale University Press, 1969. P. 47-48.

35 Decision of the ECHR of March 28, 2006 in the case of Miller v. Ukraine, stated № 23436/03. URL: http://zakon2.rada.gov.ua/laws/show/974_037. § 28-30.
} 


\section{CONCLUSIONS}

Based on the foregoing, we can draw some conclusions. If subjective law is a measure of the authorized agent's possible behavior (the right to own actions) provided by civil law and the right to demand specific behavior from other persons, the social value of such a right is manifested in the reality of its implementation to meet the needs of the copyright holder. The prevailing civilistic tradition defines the indicated concept of "measure" not as a quantitative indicator characterizing the scope of a person's powers, but as a designation of the boundaries within which an authorized entity can act. Given this, the given classical definition of subjective law, in our opinion, should take into account all the criteria provided for by law for the lawful behavior of an individual and, in particular, the established deadlines for performing the corresponding actions. Therefore, as an important conclusion, the implementation of subjective law is possible only on condition that it occurs within the time limits established for this. So, the main purpose of civil law terms is that they are designed to ensure certainty of relations, primarily in relation to the scope of powers or responsibilities of entities at a given period or time. And it is precisely thanks to such certainty that the bearer of the right or obligation has an incentive for specific materially significant actions.

Modern doctrine and legislation adhere to the thesis about the possibility of abuse of the right of its holder. It is obvious that such abuse is the commission by an authorized person of actions "in his own right", however, these actions are directed against other protected rights and interests. The boundaries of civil law are determined both by its content, the order of implementation, and the time of existence. Exit of the copyright holder beyond the specified characteristics can lead to various consequences. So, the performance by a person of actions outside the permitted behavior or the duration of the law will be considered as the actions of a person to whom the law does not belong at all. Say, continued use of property after the expiration of the lease should be qualified not as an abuse of law, but as groundless actions that are not based on the title page. Another thing is when the use of unlawful specific forms occurs within the framework of an allowed general type of behavior: this situation can be characterized as a violation of the limits of the exercise of subjective civil rights. So, the use of land in a way that entails a deterioration in the quality of the land is an abuse of their material right. The same cases must be attributed to the chicane - the use of their own substantive law exclusively to the detriment of the rights of others.

The content of the practical application of the rule on the implementation 
of subjective substantive law during the period of its existence can be reduced to the scientifically based principle of the exercise of civil rights. By its legal force, this principle consists in legislative consolidation of the general obligation for any authorized person to exercise his powers only within the content of the corresponding subjective substantive law. In other words, the implementation of subjective law is possible only within certain limits characterizing its content, term and nature of implementation. There is no doubt that the limits of the exercise of law are determined not only by its content, established in accordance with legal requirements, which are contained in specific legislation, but also by the time frame for its existence. Any actions committed by a person beyond the duration of his right should be considered an offense.

\section{SUMMARY}

The article is devoted to the legal analysis of temporary factors limiting subjective substantive rights, including with respect to the boundaries of their existence and possible implementation. A scientific distinction has been made between the concepts of "exercise of law beyond its borders" and "abuse of law". The analysis of the essential and temporal manifestations of these phenomena is made and the scientific concepts on this subject are critically investigated. It has been established that the abuse of the right is possible only when it is realized within the limits of the authority granted to the person and within the prescribed period, but is aimed at violating the rights and interests of others. That is, when acts committed "in their own right" do not comply with the legally established principle of good faith, reasonableness and justice. It is established that the timely fulfillment of a civil obligation ensures the effectiveness of the law, while unjustified delay and delay negates the application of the fairest rule of law. The doctrinal and practical approaches to guaranteeing the effectiveness of legal acts are analyzed. Proposals for improving the relevant legal tools are presented.

\section{REFERENCES}

1. Завальнюк В.В. Антропологічне осягнення правової реальності: юриспруденція на перетині епох: монографія. Одеса: Юрид. л-ра, 2012. 208 c.

2. Рабінович П.М. Ефективність права. Юридична енциклопедія: у 6 т. / за ред. Ю.С. Шемшученка та ін. Київ : Укр. енцикл, 1999. Т. 2. 744 с.

3. Грибанов В.П. Пределы осуществления и защиты гражданских прав. Москва : Российское право, 1992. 208 с. 
4. Гриценко Г.Д. Право как социокультурное явление (философскоантропологическая концепция) : дис. ... докт. филос. наук. Ставрополь, 2003. $377 \mathrm{c}$.

5. Завальнюк В.В. Ефективність права: антропологічний та євроінтеграційний аспекти. Lex portus. 2017. № 1 (3). С. 39-49.

6. Гегель Г.В.Ф. Основи філософії права, або Природне право і державознавство / пер. $з$ нім. Р. Осадчука, М. Кушніра. Київ : Юніверс, $2000.336 \mathrm{c}$.

7. Щербаков О.В. Понятие юридического срока и его процессуальный режим. Проблемь совершенствования законодательства Украинь и практики его применения: Краткие тезисы докл. и науч. сообщ. межрегиональной научной конференции молодых учёных и соискателей. Харьков : УЮА, 1991. С. 22-26.

8. Жинкин А.В. Некоторые проблемы видов эффективности норм права. Журнал российского права. 2004. № 2. С. 30-33.

9. Лейст О.Э. Сущность права: Проблемы теории и философии права. Москва : ИКД «Зерцало-М», 2002. 288 с.

10. Иоффе О.С., Грибанов В.П. Пределы осуществления субъективных гражданских прав. Советское государство и право. 1964. № 7. С. 76-85.

11. Шершеневич Г.Ф. Учебник русского гражданского права (по изданию 1907 г.). Москва : Фирма «СПАРК», 1995. 556 с.

12. Общая теория права и государства : учебник/ под ред. В.В. Лазарева. Москва : Юристь, 1999. 520 с.

13. Гуйван П.Д. Правовая природа гражданско-правовых сроков. Legea si viata. 2015. № 6/2 (282). С. 26-30.

14. Гуйван П.Д. Теоретичні питання строків у приватному праві : монографія. Харків : Право, 2014. 632 с.

15. Боднар Т.В. Строк (термін) виконання договірного зобов'язання в цивільному праві України. Вісник господарського судочинства. 2004. № 2. C. 207-212.

16. Луць В.В. Строки і терміни у цивільному праві : монографія. Київ : Юрінком Інтер, 2013. 320 c.

17. Нолькен А. Договоры в пользу третьих лиц. Санкт-Петербург : Типография императорской академии наук, 1885. 230 с.

18. Мічурін Є.О. До природи обмежень майнових прав фізичних осіб. Форум права. 2006. № 3. С. 81-86.

19. Агарков М.М. Проблема злоупотребления правом в советском гражданском праве. Москва : АН СССР, 1946. № 6. С. 422-436.

20. Флейшиц Е.А. Обязательства из причинения вреда и из неосновательного обогащения. Москва : Госюриздат, 1951. 239 с. 
21. Planiol M., Ripert G. Traite elementaire de driot civile. Paris: 1946. $285 \mathrm{p}$.

22. Поротикова О.А. Проблема злоупотребления субъективным гражданским правом. Москва : Волтерс Клувер, 2008. 280 с.

23. Малеин Н.С. Гражданский закон и права личности в СССР. Москва : Юридическая литература, 1981. 216 с.

24. Шаргородский М.Д. Наказание, его цели и эффективность. Ленинград : Издательство Ленинградского университета, 1973. 115 с.

25. Decision of theECHR ofApril 19,1993 in the case of Kraskav. Switzerland, № 13942/88, URL: http://echr.ketse.com/doc/13942.88-en-19930419/

26. Трегубов Е.Л. Право на справедливий суд в практиці європейського суду з прав людини. Форум права. 2010. № 1. С. 358-363.

27. Decision of the ECHR of November 15, 2007 in the case of Bendersky v. Ukraine, stated. № 22750/02, URL: http://zakon3.rada.gov.ua/laws/show/ 974_313.

28. Справа № 553/1254/16-ц. Архів Ленінського районного суду м. Полтава за 2016 рік.

29. Decision of the ECtHR of February 20, 1991 in the case of Vernillo v. France, № 11889/85. URL: http://echr.ketse.com/doc/11889.85-en-19910220/.

30. Decision of the ECHR of April 3, 2008 in the case of Ponomarev v. Ukraine, № 3236/03. URL: http://zakon5.rada.gov.ua/laws/show/974_434.

31. Постанова Верховного Суду України від 01 липня 2015 р. у справі № 6-178цc15. URL: http://www.reyestr.court.gov.ua/Review/46301621 .

32. Постанова Пленуму Верховного Суду України «Про строки розгляду судами України кримінальних і цивільних справ» від 01 квітня 1994 p. № 3. URL: http://zakon3.rada.gov.ua/laws/show/v0003700-94.

33. Fuller L. The Morality of Law. Yale University Press, 1969. 262 p.

34. Decision of the ECHR of March 28, 2006 in the case of Miller v. Ukraine, stated № 23436/03. URL: http://zakon2.rada.gov.ua/laws/show/974_037.

\section{Information about author:}

Guyvan P. D.,

Ph. D., Honored Lawyer of Ukraine, Professor Poltava Institute of Business Academician Yuriy Bugay International Scientific and Technical University 7, Sina str., Poltava, Ukraine

DOI https://doi.org/10.30525/978-9934-588-43-3/2.1 